\title{
Terrorism 4.0: A Global and Structural Analysis
}

https://doi.org/10.1515/openps-2018-0013

received December 7, 2018; accepted December 12, 2018.

\begin{abstract}
The paper is an analysis of the different typology, forms and aspects of terrorism in its modern incarnation. It is a critical and thorough analysis of the varied manifestations of terrorism in the international political system. The paper shows that terrorism has evolved with modernity. Terrorism in its new variation is what this paper has called 'Terrorism 4.0.' Terrorism 4.0 (T4) has two basic and definable characteristics: it is fratricidal and genocidal in nature. The paper explores the different strategies and tactics employed by various and distinct terrorist groups to destabilize states in the international political system using T4 in combination with traditional terrorism practices. By drawing on the activities of non-state actors such as ISIS, Al-Qaeda, Tehrik-i-Taliban , Al-Shabaab, Boko Haram, Hamas and Hezbollah, the paper shows that terrorism has evolved beyond its traditional conceptions in the $20^{\text {th }}$ century.
\end{abstract}

Keywords: Terrorism; Terrorism 4.0; ISIS; Structural Analysis; Boko Haram; Taxonomy.

\section{Introduction}

Terrorism is now a major feature of the international political system in the $21^{\text {st }}$ century. Terrorism in the $21^{\text {st }}$ century has gone beyond its traditional conception both in the motivations, objectives, tactics, techniques and territorial aspiration of its actors. Traditional terrorism uses kidnappings, suicide bombings (human and vehicleborne), hostage-taking, improvised explosive devices (IEDs) and armed assaults to achieve mostly political objectives. Terrorism in its present incarnation has expanded from the physical (geographical regions) into the virtual (cyberspace) and its techniques now include the use of technology-driven devices such as unmanned aerial vehicles, Twitter, Youtube and Facebook. Terrorists'

*Corresponding author: Adewunmi J. Falode, Lagos State University Ojo, Lagos, Nigeria, E-mail: adewunmi.falode@lasu.edu.ng objectives have gone beyond such abstract concepts as instilling fear, creating awareness for a particular cause and forcing governments to change specific policies, to tangible and disruptive aims like the creation of viable political, administrative, religious and territorial units. In some extreme instances, twenty-first century terrorism has made ethnic-cleansing and fratricide major parts of its objectives. Terrorism that relies on tactics like suicide bombings and armed assaults have evolved to include other forms of attacks like asymmetric warfare, cyberwarfare, cultural warfare, airplane-borne suicide bombing, the use of conventional military strategies and tactics, lone actor terrorist attacks, and genocidal and fratricidal attacks. These new formats of terrorism have altered the political and territorial landscape of states in the international political system. The fluidity with which terrorist groups combine terrorism with other forms of asymmetric conflict in the twenty-first century has made it difficult for states to evolve effective policies to tackle this hydra-headed menace. This 'new' terrorism has serious and varied consequences on states in the international political system. No region in the world is insulated from the impacts of this new facet of terrorism. Traditional terrorism, which this author has called T1, has always been region-specific and the demands emanating from the actions of non-state actors that make use of it tend to be localized. T1 is both region-specific and localized because its practitioners normally use it to challenge and force the host government to change particular policy that the group feels has adversely affected its fortunes. Twenty-first century terrorism that this author has labelled as T2, T3 and T4 is transnational in scope, impacts and objectives. Its impact is no longer limited to a specific geographical environment where the actual attacks occurred but has now extended to the periphery. A good example is the 9/11 attack carried-out against the United States by Al Qaeda. One would have thought the group would have attacked its home government in the Middle East for its proAmerican policy or target specific American installations or institutions in the area. However, Al Qaeda attacked the U.S. on its own territory. As a result of this Al-Qaedainspired and financed attack, airports the world all over have been forced to put in place extra security measures 
that have negatively affected the smooth running of air transportation. This shows that this new facet of terrorism is not only transnational but its objectives, techniques, impacts and areas of operations are no longer restricted to a particular geographical environment and government. This study is an attempt to create a tentative taxonomic classification for terrorism in the $21^{\text {st }}$ century based on the tactics and objectives of its practitioners. This is necessary because the contemporary definitions of the term is contested and it has failed to capture the dynamic and fluid variations of terrorism in the twenty-first century.

\section{Terrorism in Transition}

A lot has been written about the history, nature and typology of terrorism. Chaliand and Blin in The History of Terrorism from Antiquity to Al Qaeda give an excellent account of the history of terrorism in Western Europe and the United States. ${ }^{1}$ The work explores the development of terrorism in the aforementioned regions and focuses on the role $\mathrm{Al}$ Qaeda played in bringing the issue to the forefront of international discourse in the $21^{\text {st }}$ century. In "Online Social Networks and Terrorism 2.0 in Developing Countries," Ishengoma tries to show how terrorist groups in Africa have used the cyberspace to advance their causes. ${ }^{2}$ Using Kenya as a case study, the work shows how Al Shaabab made extensive use of Online Social Networks (OSNs) like Twitter in its attack against the Westgate shopping mall in September 2013. Nalbandov in “Terrorism 2.0. in Eurasia" shows that terrorism in Europe and Asia has transitioned from the traditional, which he calls 1.0., to the modern, which is $2.0 .^{3}$ The author argues that terrorism 1.0. is mostly 'sovereignty/ideology-driven ... and geographically limited', while terrorism 2.0. is more globalist and it champions the establishment of an Islamic caliphate in both Europe and Asia. In A Military Guide to Terrorism in the Twenty-First Century or Terrorism 3.0, the U.S. army tries to define the nature, character, tactics and strategies of modern terrorists in the $21^{\text {st }}$ century. ${ }^{4}$ The

1 Gerard Chaliand and Arnaud Blin, ed., The History of Terrorism from Antiquity to Al Qaeda (Los Angeles: University of California Press, 2007).

2 Frederick Romanus Ishengoma, "Online Social Networks and Terrorism 2.0 in Developing Countries," International Journal of Computer Science and Network Solutions (ijcsns) 1, no. 4 (December 2013), http:// www.ijcsns.com/december.2013-volume.1-no.4/article05.pdf

3 Robert Nalbandov, "Terrorism 2.0 in Eurasia," Selectedworks (2012), http://works.bepress.com/robert_nalbandov/14/

4 Training and Doctrine Command and U.S. Department of the Army, A Military Guide to Terrorism in the Twenty-First Century: U.S. work emphasizes the kind of challenges that terrorism poses for the U.S. army in the $21^{\text {st }}$ century. It carries-out an extensive analysis of terrorists' behaviour, motivations, capabilities, groups and motivations. The work shows the existential threats posed by terrorism to U.S. security forces all over the world and at the same time advance strategies that can be used to counter them.

As can be seen from the reviewed works, the extant literature on terrorism acknowledges that the study is in a constant state of flux. Traditional terrorism is now combined with new and modern tactics and strategies to achieve the broad objectives of the terrorists. Terrorist objectives have gone beyond the use of violence to create a climate of fear to include the establishment of territories after the Westphalian model. Terrorist acts are now designed by the practitioners to be region-specific. For example, some terrorist groups have global and caliphal ambitions (Islamic State in Iraq and Syria \{ISIS\}); some have regional and caliphal ambitions (Boko Haram); some are local with puritanical ambition (Al Shaabab); some are only interested in establishing economic monopolies in their region (Sinaloa cartel) and some are interested in creating political and administrative structures(FARC). The traditional structure of terrorism provided by scholars like David Brown ${ }^{5}$ can no longer provide the needed structure to capture the complexity of $21^{\text {st }}$ century terrorism. ${ }^{6}$ This researcher hopes to create a unified structure for terrorism in the $21^{\text {st }}$ century. The researcher's taxonomy takes cognisance of different efforts that other scholars have put in place to create a typology for terrorism. However, because of the obvious lacunae in such works, like the confusion over what should constitute the major narrative in $21^{\text {st }}$ century terrorism, this researcher feels it is best for a restructuring and reclassification to be done based on the objectives, tactics and motivations of its practitioners

\section{Conceptual Clarification: Terrorism, T1.0, T2.0, T3.0 and T4.0}

Terrorism is a contested term. There is no universally accepted definition of what terrorism is. It is estimated that

Army TRADOC G2 Handbook No. 1 (U.K.: Military Bookshop, August 15, 2007), https://fas.org/irp/threat/terrorism/guide.pdf

5 David Brown delineated contemporary terrorists into three broad groupings: religious, nationalist and ideologues. The metrics he used in his classification is not clearly outlined in the work.

6 David Brown, "Terrorism," in Issues in International Relations, $2^{\text {nd }}$ ed., ed. Trevor C. Salmon and Mark F. Imber (London and New York: Routledge, 2008), 107-120 
there are over 212 different definitions of terrorism in the world. ${ }^{7}$ Schmid and Jongman carried out a content analysis of over 100 definitions of terrorism. ${ }^{8}$ In the process, they discovered that the concept of violence emerged in $83.5 \%$ of definitions; political goals emerged in 65\%; causing fear and terror in 51\%; arbitrariness and indiscriminate targeting in $21 \%$; and the victimization of civilians, noncombatants and neutrals in $17.5 \%$. In the United States, Britain and Germany, there are three common elements that exist in the legal definitions of terrorism: the use of violence, political objectives and propagation of fear in a target audience. ${ }^{9}$ A cursory perusal of some scholars' definitions of terrorism also contain some or all of the identified themes (violence, fear and objective). For instance, Walter Laqueur defines terrorism as the use or the threat of the use of violence to achieve certain objectives and at the same time induce fear. ${ }^{10}$ Schmid and Jongman define terrorism as an anxiety-inspiring method of repeated violent action used by clandestine individuals, groups or state actors for political and other objectives. ${ }^{11}$ In addition, Hoffman defines terrorism as the use of violence by non-state entity designed to induce fear in the target with the aim of achieving political objectives. ${ }^{12}$ As can be seen, each of these definitions contain an essential aspect of the themes of terrorism.

In the absence of a generally accepted definition, an operational definition of terrorism will be provided and used here. Terrorism is the systemic use of violence by non-state actors to create a climate of fear with the aim of achieving political, social and religious objectives. This definition emphasizes the key denominators that one is expected to use in trying to capture the essence of terrorism: violence, fear and objective. Violence, not random violence, but deliberate and systemic violence is a key feature in most terrorist acts. The psychological aspect is also important. Hence, the desire of the terrorist to create a climate of fear and the attendant feeling of insecurity in the target state. This is an effective weapon used by the terrorists. Fear can force a state to overreact

7 Jeffrey Simon, The Terrorist Trap (Bloomington: Indiana University Press, 1994).

8 Alex Schmid and Albert Jongman, Political Terrorism: A New Guide to Actors, Authors, Concepts, Data Bases, Theories, and Literature (Amsterdam: North Holland, Transaction Books, 1988).

9 Ariel Merari, “Terrorism as a Strategy of Insurgency,” Terrorism and Political Violence 5, no. 4 (1993): 213-251.

10 Walter Laqueur, The Age of Terrorism, $2^{\text {nd }}$ ed. (Boston: Little and Brown, 1987), 143.

11 Schmid and Jongman, Political Terrorism, 28.

12 Bruce Hoffman, Inside Terrorism, $2^{\text {nd }}$ ed. (New York: Columbia University Press, 2006), 43. or underreact in its response to the terror threats. The definition also captures the objective of the terrorist act: it can be political, social, economic and religious or a combination of the four.

Terrorism 1.0 (T1) can be defined as the systemic use of violence and criminal acts by non-state actors to instil fear with the aim of achieving political objectives. The criminal acts such as kidnapping-for-ransom, stealing and armed robbery are necessary to enable the terrorist to fund its operations, especially if it does not have access to a ready pool of financial resources. It should further be stressed that the criminal acts complement and enhance the delivery of the terrorist's message. This is terrorism in its traditional form and it involves kidnapping for ransom FARC (The Revolutionary Armed Forces of Colombia) in Colombia, the use of improvised explosive devices (IEDs) (Taliban in Afghanistan), assassination of top government and military functionaries (Hamas and Hizbollah in the Middle East), hijacking (Palestinian Liberation Organization [PLO] in the Middle East) and suicide bombings in its various manifestations (Boko Haram in Nigeria).

Terrorism 2.0 (T2) specifically targets the cultural or material aspects of states. It is defined as the targeted use of violence against the material culture of a people by non-state actors to instil fear with the aim of achieving political, religious and social objectives. This is the deliberate destruction of materials of archaeological and cultural significance. The Taliban used this mode when it destroyed the statues of the Buddhas of Bamiyan in Afghanistan in 2001. ${ }^{13}$ Islamic State in Iraq and Syria (ISIS) carried this out on a larger scale when it targeted and destroyed cultural artefacts in both Syria and Iraq in $2015 . .^{14}$

Terrorism 3.0 (T3) targets the Information Communications Technology (ICT) of states, both as a means to an end and an end in itself, and the territorial legitimacy/integrity of states. T3 can be taken to be the deliberate use of violence to instil fear by non-state actors against the territorial integrity of states. The objective here is three-fold: to instil fear with the aim of achieving political objective, excise territory and make extensive use of ICT to destabilize states. Its basic nature is territorial and cybernetics. Terrorism 3.0 is territorial because its practitioners behave more like the conventional army

13 D. C. Ahir, Bamiyan Buddhas: Senseless Destruction by Taliban (India: Blumoon Books, 2001).

14 Lauren Bearden, “Complex Destruction: Near Eastern Antiquities and the ISIS Spectacle” Thesis, Georgia State University, 2016, scholarworks.gsu.edu/art_design_theses/205/. 
in a state and use asymmetric warfare (guerrilla and hybrid) to achieve its objective. The political objective is the establishment of an entity based on the Westphalian model. ISIS and Boko Haram are two good examples. In early 2015 and down to about October 2016, Boko Haram established the rump of an Islamic caliphate in three northeastern states in Nigeria. The group intermittently engaged the Nigerian army in conventional warfare during this period. ${ }^{15}$ In the cybernetics phase, terrorist use both the cyberspace (Youtube, Twitter, Facebook, WhatsApp and android applications) and autonomous aerial machines (drones) to attack and instil both psychological and physical fear in the target states. ISIS has used this to devastating effects in both the Middle East and Europe. For instance, ISIS created an android application, a video game called, 'Salil al-Sawarem,' designed to expose and lure Arab youths to the group's ideology. ${ }^{16}$

Terrorism 4.0 (T4) is genocidal and fratricidal in nature. It is the systemic use of violence by non-state actors to instil fear against a targeted group or people with the aim of achieving political and religious objectives. The political objective here is the creation of an Islamic republic that is governed by Sharia while the religious objective is to eradicate and exterminate any other type of religious association in its immediate areas of operation. T4 is genocidal because it involves the destruction of a people based on their ethnicity or race, sexual predilection and religious prepossession. The near extinction of the Yazidis in Iraq by the ISIS because of the former's religious belief is a good example. ${ }^{17} \mathrm{~T} 4$ is fratricidal because it involves the killing of a people or a group based on religious belief, even if such a belief aligns with the terrorist's own orientation. It is a fratricide if the people being killed believed in the same god as the terrorist but hold a different view of how this god should be worshipped. What comes to mind here is the distinction between the two major sects in Islam known as the Sunni and the Shia. In Iraq during the heyday of the IS, the group actively targets members of the Shia community for destruction. The Boko Haram in Nigeria targets both Christians and Muslims, especially

15 James Adewunmi Falode, "The Nature of Nigeria's boko Haram War: A Strategic Analysis," Perspectives on Terrorism," 10, no. 1 (February 2016): 41-52, www.terrorismanalysts.com/pt/index.php/ pot/article/view/488.

16 Ahmed Al-Rawi, "Video Games, Terrorism and ISIS’s Jihad 3.0," Terrorism and Political Violence (August 5, 2016): 1-21, http://dx.doi.or g/10.1080/09546553.2016.1207633.

17 Ben Smith, "ISIS and the Sectarian Conflict in the Middle East," House of Commons Library, Research Paper 15/16 (19 March, 2015): 1-66, researchbriefings.files.parliament.uk/documents/RP15-16/RP15-16.pdf. those Muslims it believe have deviated from the true and pristine tenets of Islam. ${ }^{18}$

Having dealt with the definitional and operational aspect of this work, the subsequent sections will analyze the variants of terrorism that is obtainable in the different regions of the world. The taxonomy is done based on the tactics and objectives of the various groups. It is important to state here that the list is by no means an exhaustive one but it is representative of the various facets of terrorism in the twenty-first century.

\section{Terrorism in Western Europe: The Ascendancy of T1 and T3}

Terrorist attack in Western Europe tends to be of the traditional kind. These attacks usually take the forms of hostage-taking, armed assault, suicide bombing and increasingly, lone wolf attack. Major European countries, Britain, France, Belgium and Germany have been hit by T1 attacks at various periods between 2000 and 2016 . Examples of this abound. On January 7, 2015, the Kouachi brothers and accomplices, who pledged allegiance to Al-Qaeda and ISIS, led an armed assault on the office of a French satirical newspaper in Paris. ${ }^{19}$ In the process, the terrorists killed over 12 people. It took the French authorities three days before they could kill the attackers. By then, the brothers and their accomplices had succeeded in killing about five more people therefore bringing the total to seventeen. Between September 1 and 3, 2004, thirty-two armed Chechen terrorists took 1200 people hostage in a school in Beslan, North Ossetia, Russia. ${ }^{20}$ By the time Russian security forces brought the situation under control, over 300 hostages had been killed. On April 9, 2016, thirty-two people died in multiple suicide attacks in Brussels launched by men with links to ISIS. ${ }^{21}$

Lone-wolf attack or lone actor terrorism, which requires little or no coordination and is usually low-tech,

18 Falode, "The Nature of Nigeria's Boko Haram War." 19 CNN Library, "2015 Charlie Hebdo Attacks Fast Facts," CNN, December 22, 2016, edition.cnn.com/2015/01/21/Europe/2015-paristerror-attacks-fat-facts/.

20 Adam Dolnik, “The Siege of Beslan's School No. 1," in Countering Terrorism and Insurgency in the $21^{\text {st }}$ Century: International Perspectives, James J. F. Forest (Westport, Connecticut: Praeger Security International, 2007), 177-182.

21 "Brussel Explosions: What We Know About Airport and Metro Attacks,” BBC News, April 9, 2016, www.bbc.com/news/worldeurope-35869985. 
is the most favoured form of terrorist attack in Europe. ${ }^{22}$ Germany, Belgium and France have been at the receiving end of such attacks. In most instances, the single attacker uses available everyday implement or equipment like a knife, a cutlass, an axe or a truck to carry out such attacks. This kind of attack has been very difficult to prevent and is one of the most successful in Europe. During the celebration of Bastille Day in France on July 14, 2016, a man with links to ISIS, drove a truck into a crowd of revellers in Nice killing over 82 people. ${ }^{23}$ The same pattern of attack was repeated in Germany on December 19, 2016, when Anis Amir, a 24-year old Tunisian with allegiance to ISIS, drove a truck into the midst of holiday shoppers in a Berlin market. ${ }^{24}$ This lone wolf attack resulted in the death of 12 people with another 48 people injured.

Cybernetics, an aspect of T3 attack, has been experienced in Europe. The impact of cybernetics terrorism in Europe help the terrorist achieve two important objectives: it creates a climate of fear and insecurity (psychological) and it helps the group to reach impressionable youths in Europe. Cyberspace is the favourite tool of the terrorist for spreading the group's ideology and recruiting Europeans to their cause. This is the rationale behind the upload of videos of beheadings to Youtube by ISIS. The killing of the four Americans, Peter Kassig, James Foley, Steven Satloff and Kayla Mueller, in 2014 by ISIS in the Middle East should be seen from within this context. ${ }^{25}$ As an instruction manual, the cyberspace has further helped to teach would-be lone wolf actors in Europe how to make IEDs from dual-purpose materials like pressure cookers, nails and fertilizer. A particular online magazine, Inspire, hosted by Al-Qaeda, teaches would-be terrorist how to make bombs using easily accessible materials. ${ }^{26}$ One of the Boston Marathon bombers, 19-year

22 Sam Mullins, "Jihadist Foreign Fighters and 'Lone Wolf' Terrorism," in Combating Transnational Terrorism, ed. James K. Wither and Sam Mullins (Sofia: Procon, 2016), 115-116.

23 "Nice Attack: At least 84 Killed by Lorry at Bastille Day Celebrations," BBC NEWS, July 15, 2016, www.bbc.com/news/world-europe-36800730

24 "Berlin Terror Attack: Tunisian Suspect was Investigated over Earlier Plot," The Telegraph, December 19, 2016, www.telegraph. co.uk/news/2016/12/20/berlin-market-attack-suspect-named-23-yearold-asylum-seeker.

25 "By the Numbers: Kayla Mueller Becomes the Fourth American Killed by ISIS," Syracuse," February 11, 2015, www.syracuse.com/opinion/ index.ssf/2015/02/kayla_mueller_marks_fourth_american_killed_by_ isis.ttml; "ISIS Fighters From Europe Take Lead Roles in Beheading Video,” CBSNEWS, November 17, 2014, www.cbsnews.com/news/isisexecutions-european-jihadis-take-lead-roles-in-killimg-video/

26 "Here's the Jihadist Magazine that Taught the Boston Bombers to Kill,” Gawker, April 23, 2013, gawker.com/heres-the-jihadistmagazine-that-taught-the-boston-bom-478605581. old Dhokhar Tsarnaev, learnt bomb-making through the magazine. The resulting explosion from the bomb killed three people and injured 264 others on April 15, 2013. ${ }^{27}$

$\mathrm{T} 1$ and $\mathrm{T} 3$ terrorism are driven by two major factors in Europe. The first is the fact that Europe has a large proportion of immigrant Muslims among its citizens. This immigrant Muslims came to Europe in the $21^{\text {st }}$ century because of civil wars in their countries. Syria, Libya and Iraq are good examples. Most of these immigrants find it difficult to adjust socially, culturally and of course religiously to the new environment they found themselves. Their inability to acclimatize becomes a problem when it creates a feeling of alienation and makes them to become easy prey to extremist ideology. A second factor is the easy availability of the internet. This is not a problem in itself. The combination of the internet and the freedom of expression guaranteed in most European constitution have been the factors responsible for the high incidence of terrorist attacks on the continent. Extremist clerics post their nihilistic messages and videos online. Due to the high level of internet penetration, these become easily available to the generality of the population. This explains the growth of home-grown terrorists in Europe.

\section{Terrorism in America: T1 and T3}

Terrorism in America is of the T1 and T3 variety. A qualification should be made here. The America used here can be divided into two: the north (the United States) and the south (Latin America or South America). The two Americas experience $\mathrm{T} 1$ and $\mathrm{T} 3$ terrorism, but in different degrees. Terrorist actors in the north tend to rely more on the tools of $\mathrm{T} 1$ and cybernetics. Crucially, religion plays a big factor in such terrorist attacks. In Latin America, however, acts of terrorism are usually carriedout by insurgent groups and drug cartels. Terrorism in such region is usually devoid of religious coloration. However, unlike in the north, terrorism in the region is also territorial. The insurgent group uses terrorism as a means of achieving their political objective. The Shining Path in Peru, Farabundo Marti National liberation Front (FMNL) in El Salvador and the FARC in Colombia are good examples. ${ }^{28}$

27 "Boston Marathon Terror Attack Fast Facts," CNN Library, April 8, 2016, edition.cnn.com/2013/06/03/us/boston-marathon-terrorattack-fast-facts/

28 Mark P. Sullivan and June S. Beittel, "Latin America: Terrorism Issues,” Congressional Research Service, (December 15, 2016), https:// fas.org/sgp/crs/terror/RS21049.pdf 
In the process of achieving their political objective, terrorist groups in the south use TI and aspect of T3 terrorism to engage the state militarily. Such groups usually wage asymmetric warfare against the state. The groups normally have some areas under their control from which they try to establish the microcosm of a functional state. The FARC is a good example. The FARC, formed in 1964, used to be in control of one-third of Colombia but is now confined to the heartland in the south of the country because of gains by the military. The terrorism activities of drug cartels are easily noticeable in Mexico. Examples of such Cartels are Sinaloa Cartel, Gulf Cartel, Los Zetas and La Familia Michoacana. ${ }^{29}$ Such cartels regularly resorts to mass-executions, public beheadings, public hangings, assassinations of government and military functionaries, torture and kidnappings in their turf wars. It is significant to note that the cartels are apolitical and not driven by any ideology. The major reason for their use of $\mathrm{T} 1$ and $\mathrm{T} 3$ (territorial) is purely economic.

The United States has experienced terrorism in its $\mathrm{T} 1$ and T3 (cybernetics) formats. Terrorists have targeted the U.S. for various reasons. Terrorist attacks in the U.S. are ideologically driven and religion-inspired. The country has been the targets of various international terrorist organizations like ISIS and Al-Qaeda. Terrorists used methods like suicide bombings, IEDs, lone wolf attacks (armed assault and the use of IEDs) and airplane-borne suicide bombings (Bass). For instance, on September 11, 2001, Al-Qaeda-inspired and financed terrorists hijacked four civilian airplanes mid-air and rammed them into structures in the United States. ${ }^{30}$ On June 12, 2016, a lone wolf attacker, Omar Matane, killed 49 people in a club in Orlando. ${ }^{31}$ Matane was radicalized online by ISIS. The Tsarnaev brothers' bombings of the Boston Marathon are good examples of a terrorist acts carried-out with IEDs in the United States.

Terrorists made extensive use of cyberspace in their attack against the U.S. Apart from teaching impressionable youths in the U.S how to make bombs, ISIS use slick videos on Youtube to spread its ideology and glorify jihad against America. Most of the lone wolf attackers in the U.S. like

29 June S. Beittel, "Mexico: Organized Crime and Drug Trafficking Organizations," Congressional Research Service, July 22, 2015, https:// fas.org/sgp/crs/row/R41576.pdf

30 Cindy C. Combs and Martin Slann, Encyclopedia of Terrorism, rev. ed. (New York: Facts On File. Inc, 2007), 425.

31 "Omar Mateen, Terrorist Who Attacked orlando Gay Club, Had Been Investigated by FBI," TheDailyBeast, December 6, 2016, www.thedailybeast.com/articles/2016/06/12/oamr-mateen-id-d-asorlando-killer.html
Omar Matane, Syed Rizwan Farook and Tashfeen Malik were radicalized online via the internet.

As can be seen from the analysis, $\mathrm{T} 1$ and $\mathrm{T} 3$ terrorism are particularly suited to the U.S. Terrorists attacks in the U.S. tend to be sophisticated, high-tech and of the unconventional kind. The U.S. has a sophisticated and credible counter-terrorism programme in place to deter and prevent terrorism on its soil. Hence, terrorist attackers have to be creative and sometimes 'ordinary'. This explains the use of airplane-borne suicide attacks on 9/11 and the successes of lone wolf attacks of the Orlando kind. It is difficult to have insurgency-based terrorism in the U.S. because of the following factors: the political system is established based on legitimacy; there is a clear demarcation between religion and the state; and a constitution-backed secularism.

\section{Terrorism in Africa: T1, T2, T3 and T4}

The leading terrorist organizations in the region are Al-Shabaab (Somalia) and Boko Haram (Nigeria). Others are AQIM (Al-Qaeda in the Islamic Maghreeb) Mali, AnsarAl-Sharia (Libya and Tunisia) and MUJAO (The Movement for Monotheism and Jihad in West Africa) Mali. Apart from traditional $\mathrm{T} 1$ and $\mathrm{T} 2$ terrorism, states in the region have to contend with terrorism in its territorial and fratricidal forms. A good example of a terrorist outfit that uses $\mathrm{T} 1$ and aspects of T3 (territorial) and T4 (Fratricidal) terrorism is Boko Haram. Boko Haram is a fundamentalist Islamist terror group formed in the 1990s by a Sunni-Salafi scholar called Mohammed Yusuf. ${ }^{32}$ The group's main objective is the formation of an Islamic caliphate in Nigeria and of course with it the introduction and enforcement of Sharia. ${ }^{33}$ Boko Haram's caliphal ambition extends beyond the shores of Nigeria. The group is also very active in Cameroon, Niger and Chad. ${ }^{34}$ Between 2010 and 2015, the group engaged the Nigerian army in conventional warfare. ${ }^{35}$ Prior to this period, Boko Haram had used

32 Akinola Ojo, "Nigeria's Troubled North: Interrogating the Drivers of Public Support for Boko Haram," International Centre for CounterTerrorism (ICCT), October 2013, www.icct.nl/download/file/ICCTolojo-Nigerians-Troubled-North-october-2013.pdf

33 Kyari Mohammed, "The Message and Methods of Boko Haram," in Boko Haram: Islamism, Politics, Security and the State in Nigeria, ed. Marc-Antoine Perouse de Montclos (Netherlands: African Studies Centre, 2014), 11-32.

34 Lauren Ploch Blanchard, "Nigeria's Boko Haram: Frequently Asked Questions," Congressional Research Review, March 29, 2016, https://fas.org/sgp/crs/row/R43558.pdf

35 Falode, “The Nature of Nigeria's Boko Haram War” 
guerrilla tactics against the Nigerian security forces sent to check its activities in the conflict zone. By mid-2015, the group had succeeded in establishing the microcosm of a functional Islamic caliphate on territories claimed from Nigeria in the northeast. ${ }^{36}$ A very effective tactic of the group is the use of large-scale abductions to generate new recruits, wives for the fighters and ransom money that is then ploughed back into obtaining more materiel for the Boko Haram. In April 2014, the group kidnapped over 270 Chibok girls from their school dormitory in Maiduguri. ${ }^{37}$ The group further kidnapped over 97 boys and men in some Bornu villages in August of the same year. ${ }^{38}$ The conflict has killed over 20,000 Nigerians between 2010 and 2015. This is why the Institute of Economics and Peace, a global think-tank on peace, named Boko Haram the deadliest terror group in the world in 2016. ${ }^{39}$

Boko Haram's terrorism is also fratricidal. The group's ideology, political and social existence is rooted in Islam. This has however not stopped Boko Haram from targeting Muslims and their religious places of worship. In September 2015, a bomb placed in a mosque by Boko Haram in Maiduguri city killed 94 worshippers when it detonated. ${ }^{40}$ A Boko Haram suicide bomber killed 21 Shiites in the middle of a religious procession in Kano on November 27, 2015. ${ }^{41}$ In August 5, 2016, Abu Musab al-Barnawi, named the new leader of Boko Haram by ISIS, publicly accused the erstwhile leader, Abubakar Shekau, of murdering several members of the group in cold blood..$^{42}$

36 Falode, “The Nature of Nigeria's Boko Haram War"

37 Benjamin Maiangwa and Olumuyiwa Babatunde Amao, "Daughters, Brides, and Supporters of the Jihad: Revisiting the Gender-Based Atrocities of Boko Haram in Nigeria," African Renaissance 12, no. 2 (2015): 117-144.

38 "Boko Haram," Counter Extremism Project, accessed January 8, 2017, www.counterextremism.com/threat/boko-haram.

39 “Global Terrorism Index 2016," Institute for Economics and Peace, accessed January 8, 2017, http://economicsandpeace.org/wpcontent/uploads/2016/11/Global-Terrorism-Index-2016.2.pdf

40 "Boko Haram: Bombing Campaign Sees Civilian Deaths Spiral," Amnesty International (September 24, 2015), https://www.amnesty. org/download/Documents/AFR4424982015ENGLISH.pdf

41 "A Suspected Boko Haram Bomber Kills 21 Shiites in the Middle of a Religious Procession from Kano to Zaria, Nigeria," New York Times, November 27, 2015, https://www.nytimes.com/2015/11/28/ world/africa/nigeria-boko-haram-is-suspected-as-suicide-bomberkills-21-shiites.html

42 Jacob Zenn,"Boko Haram: Abu Musab al-Barnawi's Leadership Coup and Offensive in Niger," Terrorism Monitor XIV, issue 17 (August 19, 2016), https://jamestown.org/wp-content/uploads/2016/08/TM_ vol_14_issue_17.pdf; "New Boko Haram Leader, al-Barnawi, Accuses Abubakar Shekau of Killing Fellow Muslims, Living in Luxury," Sahara Reporters, August 5, 2016, saharareporters.com/2016/08/05/ new-boko-haram-leader-al-barnawi-accuses-abubakar-shekaukilling-fellow-muslims-living
Al-Shabaab is a fundamentalist Wahabbi Sunni Islamist terror organization in Somalia. ${ }^{43}$ It was established in 2006 and it is allied to Al-Qaeda. The group's main objective is the establishment of an Islamist state in Somalia governed by strict Sharia law. ${ }^{44}$ The group has engaged the Somali government in intermittent and protracted conflict and has been able to prise territories from the state. Al-Shabaab controlled vast territories in both southern and central Somalia including Diinsoor, Baraawe, Kismayo and Mogadishu. ${ }^{45}$ Being a land-holding terror group like Boko Haram and ISIS, Al-Shabaab uses guerrilla tactics, asymmetric and conventional military strategies against the Somali state. Al-Shabaab uses T1 tactics such as assassination of both military and government officials, kidnapping, suicide bombings and IEDs. On December 3, 2009, at a university ceremony in Somalia, the group launched a suicide attack that killed three cabinet ministers, dozens of students, parents, professors and scores of graduating medical students. ${ }^{46}$ From its base in Somalia, the group launches regular attacks into Uganda, Kenya and Ethiopia. On September 21, 2013, Al-Shabaab gunmen attacked the Westgate shopping mall in Nairobi, Kenya. ${ }^{47}$ The group took some hostages, including foreigners, and it took Kenyan security forces four days to bring the situation under control. In all, the assailant succeeded in killing 67 hostages and wounding over 200 others.

The United Nations was forced to act to guarantee stability in Somalia since there was no effective central governing authority in the country. The U.N. established AMISOM (African Union Stabilization Mission) in conjunction with the A.U. in January 2007 to fight the group and create a functional democratic government in Somalia. AMISOM members are Uganda, Kenya, Ethiopia and Burundi- states directly affected by the terror activities of Al-Shabaab. Through the military engagements of AMISOM, Al-Shabaab has lost swathe of territories and districts in Somalia, though it is still entrenched in the larger part of southern Somalia. ${ }^{48}$ Besides, Al-Shabaab

43 Abdirahman "Aynte" Ali, "The Anatomy of al-Shabaab," Terrorism Research and Analysis Consortium (TRAC), accessed January 10, 2017, https://www.trackingterrorism.org/sites/default/ files/chatter/TheAnatomyOfAlShabaab_0.pdf on January 10

44 Hussein Solomon, Terrorism and Counter-Terrorism in Africa: Fighting Insurgency from Al Shabaab, Ansar Dine and Boko Haram (London: Palgrave Macmillan, 2015), 39-58

45 Ali, "The Anatomy of al-Shabaab," 2

46 Ali, "The Anatomy of al-Shabaab," 5

47 Lauren Ploch Blanchard, "The September 2013 Terrorist Attack in Kenya: In Brief,” Congressional Research Service (November 14, 2013) https://fas.org/sgp/crs/row/R43245.pdf

48 Sunguta West, "Al-Shabaab Aims For 'Hearts and Minds' with Establishment of Islamic Police Force," Terrorism Monitor XIV, 
has an internationalist outlook. It believes in a global jihad. The group is very active in cyberspace. The group uses the cyberspace to espouse its brand of radical Islam, encourage lone-wolf attacks against the U.S. and to get new converts in the West and in Africa. In fact, the BBC (British Broadcasting Corporation) has named Al-Shabaab the terror group with the most effective online presence in Africa because of its prolific use of Twitter. ${ }^{49}$ It uses Twitter regularly to stream its attack and provide real-live updates to counter the official narratives about its activities.

Ascan beseen from theanalysis, Africa has experienced terrorism in the four formats. The factors responsible for this are legitimacy, religion and ineffective security forces. Legitimacy here means the refusal of a significant portion of the population of the state to recognize the authority of the central government to govern. This can be due to the fact that the ruling elites rigged its way into the seat of power or because a particular ethnic or religious group feels it has not been adequately represented at the centre. This has also created the problem of ungoverned spaces in most countries in Africa. An ungoverned space is a region within a state where the presence or authority of the government is absent. Most countries in Africa have lots of ungoverned spaces. Most non-state actors have exploited these spaces to establish footholds on the continent. This factor explains the success of $\mathrm{T} 1, \mathrm{~T} 3$ and $\mathrm{T} 4$ terrorism in Africa. Religion is a polarizing factor in Africa. Unlike in the U.S. and Europe, where there is religious relativity, terrorist groups have capitalized on religious intolerance in Africa to advance their different causes. A major reason for this intolerance is the vaguely defined secularism of countries on the continent. This factor again explains the high incidence of $\mathrm{T} 1, \mathrm{~T} 3$ and $\mathrm{T} 4$ terrorism on the continent. Moreover, terrorism on the continent normally transitions to insurgencies due to the inability of the security forces to put in place effective counter-terrorism strategy. Some of the factors responsible for this are: lack of funds to create and train counter-terrorism units; nonexistent or underdeveloped intelligence-gathering units; use of obsolete weapons to prosecute counter-terrorism campaigns; non-creation of programmes to counter violent extremism; and the failure of states to adapt and evolve in the fluid and dynamic terrorism environment.

issue 17 (August 19, 2016): 3-5, https://jamestown.org/wp-content/ uploads/2016/08/TM_vol_14_issue_17.pdf

49 "Africa's Militant Islamist Groups," $B B C$ NEWS, December 6, 2013, www.bbc.com/news/world-africa-24587491

\section{Terrorism in the Middle East: $\mathrm{T} 1, \mathrm{~T} 2, \mathrm{~T} 3$ and $\mathrm{T} 4$}

The Middle East is one region in the world where terrorists have established extreme stronghold. The region has experienced terrorism in the four formats. Groups like Hamas and PLO (Palestinian Liberation Authority) use traditional T1 terrorism like the assassination of government and military personnel in Israel; ISIS uses T2 terrorism to destroy cultural landmarks; Al-Qaeda and ISIS use T3 terrorism to destabilize the West psychologically and recruit new members from the international community; and ISIS uses T4 terrorism to target a particular group based on ideology, religion, race or sexual preference. In the case of Israel, terrorist groups like the PLO, Hamas and Hezbollah have traditionally used suicide bombings, IEDs, armed assaults to destabilize the state. However, because of the sophistication of the Israeli security forces, it is increasingly difficult for terrorists to carry out largescale attack in that country. Terrorism in Israel now relies on lone wolf actors that utilize easily available materials to launch such attacks. For example, on January 8, 2017, a lone wolf terrorist drove a truck into the midst of soldiers in Jerusalem. ${ }^{50}$ The attack left four Israeli soldiers dead and fifteen seriously injured. This kind of attack is very difficult to anticipate and prevent.

Islamic State in Syria, an offshoot of Al-Qaeda in Iraq, was established by Abu Mus'ab al-Zarqawi in 2003. Ideological differences forced the group to splinter from Al-Qaeda and Abu 'Umar al-Baghdadi eventually became its leader in $2010 .^{51}$ The group is a Sunni religious sect that espouses a violent and extremist brand of Islam. ISIS's theological underpinning is Salafism and this religious ideology underpins the terror movement. Salafist believes in the literal interpretation and application of the Quran and Hadith. Under Baghdadi, ISIS became a global terror hegemon. Baghdadi declared the ISIS as a caliphate on June 29, 2014. The major objective of the group is the establishment of the Islamic caliphate, first in the Middle East, and then the rest of the world. To achieve this objective, the group launched a global jihad to counter forces, both local and international, opposed to the ISIS

50 “4 Killed in J'lem Terror Attack; Rivlin: Terror Won’t Break Us,” The Times of Israel, January 8, 2017, www.timesof Israel.com/ liveblog-january-8-2017/

51 Cole Bunzel, "From Paper State to Caliphate: The Ideology of the Islamic State," Center for Middle East Policy, no. 19 (March 2015): 7-11, https://www.brookings.edu/wp-content/uploads/2016/06/Theideology-of-the-Islamic-State.pdf 
caliphate declared on June 29, 2014..$^{22}$ By December 2014, the group had succeeded in taking cities and territories such as Mosul, Tikrit, Fallujah and Anbar province from Iraq and Palmyra, Kobani, Raqqa and much of the east from Syria. ${ }^{53}$ It was able to do this because it carried out large-scale conventional military attacks using tanks and artillery taking from defeated Iraqi armed forces. For example, ISIS used conventional military tactics to overrun Mosul in June 2014 and took it from the Iraqi army. ${ }^{54}$ By 2015, ISIS established the Caliphate as a political entity on territories that straddled both Iraq and Syria, and had instituted its strict interpretation of Islam. Besides, ISIS made extensive use of T2 terrorism. This can be seen in the destruction of archaeological artefacts in Iraq and its museum and famously, the destruction of the ancient archaeological sites in Palmyra in Syria in 2015..$^{55}$ Using T3 terrorism, ISIS used guerrilla tactics, asymmetric and conventional warfare to confront the Iraqi and Syrian security forces. The successes the group recorded from these various engagements made it possible for ISIS to establish territorial foothold on both Iraq and Syrian territories.

Furthermore, ISIS made extensive use of the cyberspace. ISIS has websites such as 'Jihad Platform Media' and 'Islamic State Archive'; blogs such as 'The Islamic State Blog'; and makes extensive use of social media sites like Facebook, Twitter and Youtube. ${ }^{56}$ The group is a prolific user of Youtube. Videos of its exploits on the battlefield, the religious administration of the caliphate, messages from its suicide bombers and the regular beheadings of hostages are frequently uploaded to the video-sharing site. Apart from that, the group also has an online magazine, Rumiyah, that it uses to recruit new adherents and at the same time exhorts its sympathizers in the West to carry out lone wolf attacks. ${ }^{57}$ In late 2016, evidence surfaced that ISIS has weaponized commercial

52 Elliot Friedland, “Special Report: The Islamic State,” The Clarion Project (May 10, 2015), https://www.clarionproject.org/sites/default/ files/islamic-state-isis-isil-factsheet-1.pdf

53 Patrick Cockburn, The Rise of the Islamic State: ISIS and the New Sunni Revolution (London: Verso, 2015), 7-11.

54 Cockburn, The Rise of the Islamic State, 7

55 Bearden, "Complex Destruction:”; “Tracking a Trail of Historical Obliteration: ISIS Trumpets Destruction of Nimrud,” CNN, April 14, 2015, edition.cnn.com/2015/03/09/world/Iraq-isis-heritage/

56 Luna Shamieh and Zoltan Szenes, "The Propaganda of ISIS/ DAESH Through the Virtual Space,” DATR (April 30, 2015): 7-13, http://www.coedat.nato.int/Publication/datr/volume10/02ThePropaganda_of_ISIS_DAESH_through_VirtualSpace.pdf

57 Elliot Friedland, "Latest Issue of ISIS Rumiyah Magazine Released,” The Clarion Project, October 11, 2016, www.clarionproject. org/analysis/latest-issue-isis-rumiyah-magazine-released drones with grenade-sized bombs. ${ }^{58}$ ISIS also uses T4 terrorism, fratricide and genocide, to achieve its objectives of creating a pristine and ultra-orthodox Islamic caliphate. The group targets people of different sexual orientation, religion and race or tribe. The case of the Yazidis is a good example. ISIS also targets Shiites, Alawites, indigenous Assyrian population in Iraq and homosexuals. In June 2014, ISIS executed 1700 Shiites that had been freshly recruited into the Iraqi army..$^{59}$ Additionally, ISIS buried 45 of its members alive in May 2016 as punishment for cowardice in battle against Iraqi military forces. ${ }^{60}$

It should be noted that the major drivers for the different facets of terrorism in the region are religion and political legitimacy. Unlike in Europe, the U.S. and Africa, rivalry in the region is both intra- and inter-religious. There is the traditional one between two different religions or faiths (Islam/Christianity); and the other between different sects in the same religions (Sunni/Shia). Yet, there are those between Judaism and Islam and Islam and animism. Most of the terror outfits in the region professes their desire to establish an Islamic caliphate in the Middle East. This factor resonates among the vast majority of people that inhabits the region because the origin of Islam is located in the Middle East. For example, the desire to create an Islamic caliphate is a driving force behind the activity of ISIS in both Syria and Iraq. Legitimacy becomes an issue because of the intertwined relationship between religion and politics in the region. States that espouse Western-style system of government and secularism are seen to be anti-Islam and therefore illegitimate. The terrorists use this refrain to undermine the state and win adherents to its cause. Since most of the states in the region are totalitarian in nature, the terrorists then resort to extreme force (T1, T2, T3 and T4 terrorism) to achieve their objectives. The legitimacy factor also explains why it has been easy for terrorism to transmute to insurgency in the region.

58 Jeff Schogol, "ISIS Using Small Drones to Drop Bombs on Iraqis," MilitaryTimes, January 11, 2017, www.militarytimes.com/articles/isisusing-armed-drones

59 "Escaping Death in Northern Iraq: Surviving an ISIS Massacre," The New York Times, September 3, 2014, https://www.nytimes. com/2014/09/04/world/middleeast/surviving-isis-massacre-iraqvideo.html? $=0$

60 "ISIS Bury 45 of their Own Fighters Alive After they Fled the Battlefield,” Mirror, May 11, 2016, www.mirror.co.uk/news/worldnews/isis-bury-45-fighters-alive-7943328 


\section{Terrorism in Asia: T1, T2, T3 and T4}

Terrorist in Asia made use of the different terrorism formats to achieve their objectives. Groups like Tamil Tigers, Taliban, Abu Sayyaf, Al Badr and Tahrek-e-Taliban Pakistan (TTP) have long terrorised different countries in the region and in the wider world. Terrorist groups in the region made extensive use of T1, T2, T3 and T4 terrorism. Al Qaeda is a Sunni terrorist group formed in 1988 in Peshawar, Pakistan by Osama Bin Ladin and his associates. ${ }^{61} \mathrm{Al}$ Qaeda's main objective is the establishment of a global jihadi movement meant to cleanse Islam of all impurities first in the Middle East and then the rest of the world. It is a transnational terrorist organization and as such, Al Qaeda has carried-out series of attacks in Africa, Asia, the Middle East, Europe and the United States. To achieve its broader aim of cleansing Islam, Al Qaeda established franchises in the different regions of the world: Al Qaeda in the Arabian Peninsula (AQAP); Al Qaeda in Iraq (AQI) and Al Qaeda in the Islamic Maghrib (AQIM). Al Qaeda uses T1 (suicide bombings, IEDs, kidnapping, aspects of T3 (cyberspace) and T4 (fratricide) terrorism to achieve its objective.

Al Qaeda pioneered the use of airplane-borne suicide bombing in 2001. This will be the first time a foreign-based terror group will attack America on its own soil. Al Qaeda frequently uses armed assaults, IEDs, human and vehicleborne suicide bombings in attacks in America, Europe, Asia, Africa and the Middle East. For example, on March 11, 2004, simultaneous bombings of four packed commuter trains by Al Qaeda operatives left 191 people dead and 1800 injured in Madrid, Spain..$^{62}$ In a similar vein, four Al Qaeda suicide bombers launched coordinated attacks on three London Underground trains and a doubledecker bus killing 57 people and injuring 700 others on July 5, 2005. ${ }^{63} \mathrm{Al}$ Qaeda also uses the cyberspace to get its messages directly to the target audience in Europe, Asia, the U.S., the Middle East and Africa. The online jihadi magazine, Inspire, espouses its ideology and at the same time disseminates information and exhortations to those who would want to carry-out lone wolf attacks. ${ }^{64}$ Just

61 Philippe Migaux, "Al Qaeda," in The History of Terrorism from Antiquity to Al Qaeda, Chaliand and Blin, 314-347

62 "Al-Qaeda Attacks in Europe since September 11," The Telegraph, March 21, 2012, www.telegraph.co.uk/news/worldnews/ al-qaeda/9157929/Al-Qaeda=attacks-in-Europe-since-September-11. html.

63 "Al-Qaeda Attacks in Europe since September 11,"

64 "Al Qaeda's Online Magazine Tells Terrorists to Targets U.S. Business Leaders in their Homes," The Washington Times, May 15, 2016, www.washingtontimes.com/news/2016/may/15/al-qaedasonline-magazine-tells-terrorists-to-targ/; “Jihad Magazines,” Global like ISIS in the Middle East, Al Qaeda considers Shiites its mortal enemy. It has launched a series of devastating attacks on Shiites in both Asia and the Middle East. For instance, a major bomb attack against a Shiite mosque in Najaf killed the leader of the Supreme Council of the Islamic Republic of Iraq on August 29, $2003 .{ }^{65}$

Legitimacy and religion are two important factors responsible for the high incidence of T1, T2, T3 and T4 terrorism in Asia. There exist swaths of ungoverned spaces in some countries in the region. This has made it possible for terrorist groups to set-up shops and establish quasi-statelet. For example, Waziristan and Baluchistan in Pakistan have within it such spaces where the authority and presence of the state is non-existent. From here, untouched and undisturbed by the central authority, the terrorist groups have been able to develop and become existential threats to states in and beyond the region. This explains the insurgency-like feature of terrorism (T3) in that part of the world. Moreover, religion, just like in the Middle East, is a major factor driving terrorism in the region. The intertwined relationship between religion and politics has created an incompatibility that the terrorist have exploited. Some states in the region, like Afghanistan and Pakistan, try to espouse Western-style democratic system that extremists see as being incompatible with their faith. To force such states to embrace pristine Islam, the extremists resort to terrorism.

\section{Conclusion}

Terrorism has always been a contested term in the definitional sense. Added to this, in the twenty-first century, the term picked up some new interesting features: some aspect of it are now fratricidal, genocidal and territorial. This has further muddled the 'accepted' operational and definitional aspect of the term. This work has created a tentative taxonomy for terrorism in the twenty-first century based on the tactics and objectives of its practitioners. This paper does not in any way claim to be the definitive work on the taxonomy of terrorism in the twenty-first century. The significance of the paper lies in the fact that it has shown that terrorism and its practitioners have become dynamic and adaptive in the $21^{\text {st }}$ century. Most significantly, terrorist groups now deploy strategies

Terrorism Research Project, accessed January 22, 2017, https://dsdrupal.haverford.edu/aqsi/resources/Jihadi-magazines

65 Kenneth Katzman, "Al Qaeda in Iraq: Assessment and Outside Links," Congressional Research Service, August 15, 2008, https://fas. org/sgp/crs/terror/RL32217.pdf 
and tactics that are region-specific in the targeted areas based on the areas of weakness of the host government. The terrorism practised in Africa, this paper has shown, is not the same as the one in Western Europe. The terrorism that is practised in the Middle-East is different from that of Latin America. In fact, while terrorist attacks in the West tend to be of the ordinary type, such as lone wolf attacks and the use of articulated trucks in crowded places, attacks in Africa and the Middle East tends to be more technologydriven. Terrorism in Africa, Asia and the Middle-East tend to have political, social, religious and territorial objectives. Examples of terrorist groups that have translated their terror campaigns to territorial gains are ISIS in the MiddleEast, Boko Haram in Nigeria, Al-Shaabab in Somalia and the Taliban in Afghanistan. Crucially, the modern brand of terrorism practised in the Middle East has also embraced the destruction of a group based on ethnicity or race, what is known as genocide. Interestingly, while such attacks in Europe and the United States are meant to send political messages or force a change in specific policies by the target states, terrorism in Africa, the Middle-East and Asia has a broader objectives and characteristics. Finally, the paper has shown the tendency of terrorist groups to combine the techniques identified in the taxonomy to achieve their various objectives. 